\title{
Microbiological evaluation of certain fruits and vegetables marketed in the city of Kenitra-Morocco
}

\author{
Rahma Erahioui ${ }^{* 1}$, Sultana INEKACH ${ }^{I}$, Hassna JABER ${ }^{I}$, Khadija ATFAOUI ${ }^{1}$, Noureddine RHAIM ${ }^{I}$, Zakaria \\ MENNANE2 and Mohammed OUHSSINE ${ }^{1}$.
}

${ }^{1}$ Full Address: Laboratoire d'Agrophysiologie Biotechnologie Environnement et Qualité, Département de Biologie, Faculté des Sciences, Université Ibn-Tofail Kenitra-Maroc.

${ }^{2}$ Laboratory of Biology and health University Abdelmalek Assaadi, BP 2117 Tetouan-Morocco.

The corresponding author E-mail: rahma.erahioui@uit.ac.ma

\begin{abstract}
Fruits and vegetables are essential for human health due to their nutritional qualities, but the consumption of raw foods leads to food safety problems as they are recognized as sources of transmission of infectious diseases. The objective of this work is to assess the microbiological quality of some fruits and vegetables marketed in the Kenitra city. The samples were purchased at the fruit and vegetable markets during the period from April to July 2018. The detection of microorganisms in the samples requires several steps which are weighing, dilution, isolation, enumeration and 'identification. The results of the microbiological analysis of fruits and vegetables studied show significant concentrations of the total aerobic mesophilic flora varies between 2.25 and $8.48 \log 10 \mathrm{CFU} / \mathrm{ml}$, Concerning total coliforms the contamination rates vary between 1.92 and $8.42 \log 10 \mathrm{UFC} / \mathrm{ml}$, as well as the presence of fecal coliforms between 1.13 and $8.05 \log 10 \mathrm{UFC} / \mathrm{ml}$, in the same samples analyzed, strains such as: Escherichia coli, staphylococcus aureus and a total absence of salmonella and shegilla. In order to improve the safety and hygienic quality of fruits and vegetables, the application of good hygienic practices as well as continuous microbial quality control is necessary to protect the health of consumers.
\end{abstract}

Keywords: fruits, vegetables ,microbiological analysis, quality.

*Corresponding author: rahma.erahioui@uit.ac.ma 


\section{INTRODUCTION}

Fruits and vegetables are essential for human health because of their nutritional qualities [1]. Consumption of a serving of 400 to $600 \mathrm{~g}$ of fruit and vegetables per day is recommended by the WHO, FAO and the Fund global cancer research [2]. But the consumption of fruits and vegetables sometimes poses food safety problems, recognized as an important source of transmission of infectious diseases [3]. In a study carried out in the region of Gharb Chrarda Bni Hssen, fruits and vegetables were the main causes of collective poisoning [4]. Indeed it is a region located in the Sebou valley recognized for its pollution. The United Nation organization for food and agriculture upstream and its impact on agriculture downstream which explains the predominance of water-borne contamination (fruits and vegetables) in favor of food contamination of animal origin [4].

It is known that salads constitute an essential part of the human diet [5].

Researchers from the Centers for Disease Control and Prevention have analyzed American reports of food poisoning for more than ten years, in 2013 released a list of 17 foods that cause the most poisonings, hospitalizations and deaths [6 ].

Food poisoning is a common illness that is usually mild, but sometimes can be fatal. It occurs when a person ingests a food or drink contaminated with a bacteria or toxin. Toxins from chemicals or pesticides can sometimes cause food poisoning [7]. According to the WHO, a disease of an infectious or toxic nature caused by agents that enter the body through ingested food [8]. In Morocco between the years 1992-2011 a number of 19,625 cases of food poisoning, of 5,688 hospitalizations and 221 deaths [8].

General marketing standard set by the Community regulation for fresh fruit and vegetables which are developed in Regulation No. 543/2011 laying down detailed rules for the application of Regulation No $1234 / 2007$ in the fruit and vegetables sector [9].

The objective of our study is to assess the microbiological quality of raw fruits and vegetables marketed in the Kenitra city.

\section{Materials and methods}

The samples (fruits and vegetables) were purchased at the fruit and vegetable markets during the period from April to July 2018. The samples were transferred in sterile plastic boxes. The distance between the place of sampling and the laboratory is 5 to 8 min during transport. We begin with the preparation of the stock solution and then vary depending on the desired germ, hence the variation in the culture medium used, the temperature and the incubation time.

\subsection{Preparation the samples (NM ISO 68871) [10]}

A mass of $25 \mathrm{~g}$ of each sample was solubilized in $225 \mathrm{ml}$ of physiological water in a stomacher bag to prepare the stock solution [11].

Cascading decimal dilution series were made under aseptic conditions. $1 \mathrm{ml}$ of each dilution used for the enumeration of microorganisms. We have mainly worked on the most consumed foods, the search for microorganisms in the samples requires several steps which are weighing, dilution, isolation, enumeration and identification [12].

\subsection{Methods of finding and counting germs Enumeration of FMAT (NM ISO 4833; 2008)}

Placed in a sterile petri dish, a deep inoculation is carried out by adding $15 \mathrm{ml}$ of the Plate Count Agar (PCA) nutrient agar medium by incorporation. Incubated at $+30 \mathrm{C}$ for 24 hours, After incubation, the small white colonies are counted. Characteristics of FMAT [13].

\subsection{Enumeration of fecal and total coliforms (NM ISO 4832; February 2006)}

The research was carried out on the VRBL medium by incubation at $37^{\circ} \mathrm{C}$ for 24 hours. The enumerations of all characteristic colonies were made according to standard [14].

\subsection{Determination of Escherichia coli (NM ISO 16649-2; April 2001)}

For the determination of Escherichia coli, the culture media (MaCconkey and EMB) were incubated at $37^{\circ} \mathrm{C}$ for 24 hours [15].

\subsection{Enumeration of Staphylococcus aureus (NM ISO 6888-1; 1999)}

The enumeration of S. aureus colonies was carried out on solid medium (Baird Parker medium) after incubation at $37^{\circ} \mathrm{C}$ for 24 to 48 hours [16]. 


\subsection{Enumeration of Clostridium perfringens germs (NF ISO 7937; 2005)}

Inoculation of our samples prepared previously in Tryptone-Sulfite-Cycloserine agar and incubate the petri dishes aerobically between 35 and $37^{\circ} \mathrm{C}$ and observe the results after 18 to $24 \mathrm{~h}$ [17].

\subsection{Detection of Salmonella and shegilla (ISO}

\section{9; 2002)}

Was made according to the AFNOR method (French Normalization Agency) in 4 steps:

pre-enrichment to recover bacteria that have undergone stress; then a selective enrichment, favoring the multiplication of salmonella in relation to the competing flora; followed by isolation on specific selective media and biochemical and molecular identification [18].

The dish is incubated at $37^{\circ} \mathrm{C}$. for 24 hours. Then the characteristic colonies are picked and seeded on the nutrient agar.

For confirmation tests, either enterotubes or API galleries are used. According to Standard V 08-052 (May 1997) [19].

\subsection{Identification technique}

\subsubsection{Gram stain [20]}

Coloring with gentian violet or crystal violet.leave to act for 30 seconds, rinse with demineralized water Spread the lugol and let it act for 1 minute. Rinse with deionized water Ethanol decoloration pour dropwise, and monitor the decoloration (5 to 10 seconds). The net should be clear at the end of the discoloration. Rinse with demineralized water, Recolouring with safranin or fuchsin. Leave on for 30 seconds to 1 minute, Wash gently with demineralized water in progress. Dry the slide on a hot plate at $40^{\circ} \mathrm{C}, 10$ to 15 minutes. Observe with a drop of objective 100 immersion oil (magnification x1000).

\section{Microscopic observation [21]}

Studying microbial morphology under a light microscope means researching the shape of bacteria and their grouping mode.

\subsubsection{Kligler test, Citrate and Mannitol [21]}

For the three environments in fact:

Inoculate using a Pasteur pipette loaded with suspension of the culture to be studied: - the slope in streaks (without reloading the pipette between the slope and the pellet).Incubate 24 hours at $37^{\circ} \mathrm{C}$.

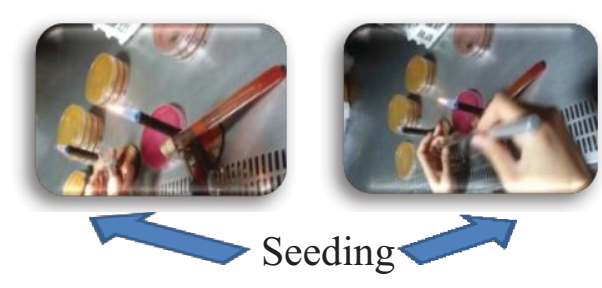

\subsubsection{Confirmation Test (ref. 20 100) [21]:}

You must first have developed a bacterium in isolated colonies in a Petri dish to identify Gram - bacilli belonging to the ENTEROBACTERIACEAE family.Gallery of 20 ready-to-use microtubes for performing 23 biochemical tests. We create an anaerobiosis in the ADH, LCD, ODC, URE, H2S tests by filling their well with paraffin oil.Close the incubation box and place it in the incubator at $35-37^{\circ} \mathrm{C}$ for 18-24 hours.

\subsubsection{Confirmation by Galleries [21]}

Microtube cup containing the dehydrated medium the bacterial suspension introduced into the tube dissolves the dehydrated substrates.

Combine the bottom and lid of an incubation box and distribute approximately $5 \mathrm{ml}$ of water in the cells to create a humid atmosphere.

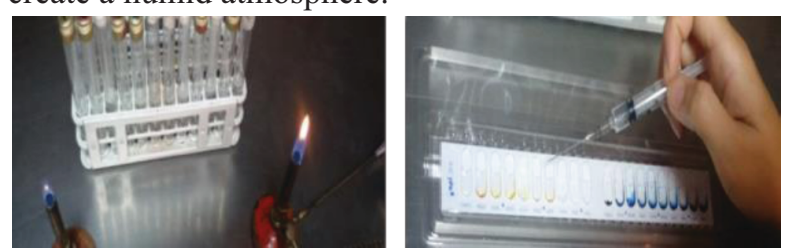

Figure: Bacterial suspension Figure: Seeding the gallery Microtube cup containing the dehydrated medium the bacterial suspension introduced into the tube dissolves the dehydrated substrates.

Combine the bottom and the lid of an incubation box and distribute approximately $5 \mathrm{ml}$ of water in the cells (with a graduated pipette) to create a humid atmosphere.

The analysis of our data was done by Microsoft Office Excel 2007.

\section{Results and discussion}

The results of our study to assess the microbiological quality of the most consumed fruits and vegetables are noted above:

\subsection{Microscopic observation}

From our microscopic observation we found bacterial strains. Among them E. Coli, Shegilla, Salmonella which presents a bacillus in the form of elongated rods with gram negative, the same for Clostridium but with gram positive. While Staphylococcus aureus is a gram positive bacterium that presents in the cocci form.

\footnotetext{
Corresponding author: rahma.erahioui@uit.ac.ma
} 
Table 1: microscopic observation of bacterial strains

\begin{tabular}{|c|c|c|}
\hline Strains & Form & Gram \\
\hline E. coli & Bacillus & - \\
\hline $\begin{array}{c}\text { Staphylococcus } \\
\text { aureus }\end{array}$ & Cocci & + \\
\hline Clostridium & Bacillus & + \\
\hline Shegilla & Bacillus & - \\
\hline Salmonella & Bacillus & - \\
\hline Proteus (PR) & Bacillus & - \\
\hline $\begin{array}{c}\text { Pseudomonas } \\
\text { (PS) }\end{array}$ & Bacillus & - \\
\hline Clostridium & bacillus & + \\
\hline Streptococcus & cocci & + \\
\hline Klibseilla & Bacillus & - \\
\hline
\end{tabular}

\subsubsection{Kligler test, Citrate and Mannitol}

A turn to blue for Simmons citrate + Bacteria using citrate as a single carbon source phenomenon of alkalization, on the other hand for Simmons citrate - no turn bacteria not use it. Bacteria can use citrate as the only carbon source which can be explained by use by fermentation since Enterococci are not able to use oygen.

Table 2: Test the strains by Kligler test, Citrate and Mannitol

\begin{tabular}{|c|c|c|c|c|}
\hline Strains & LACTOSE & GLUCOSE & H2S & GAS \\
\hline E.coli & + & + & - & + \\
\hline Staphylococcus & + & + & + & + \\
\hline Clostridium & + & + & - & + \\
\hline Shegilla & - & + & - & - \\
\hline Salmonella & - & + & - & + \\
\hline Proteus & - & + & - & - \\
\hline Pseudomonas & + & + & + & + \\
\hline
\end{tabular}

\subsubsection{Example of E. coli}

Escherichia coli is a mobile enterobacterium characterized by the fermentation of glucose + , the production of indole + , TDA-, indole ++ , VP-, does not have urease, does not produce $\mathrm{H} 2 \mathrm{~S}$ and is unable to assimilate citrate as the only aerobic carbon source.

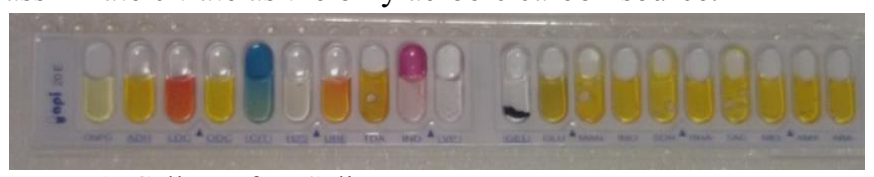

Image 1: Gallery of E. Coli

\subsection{Biochemical characters}

The study allowed us to determine the real discriminating power of the biochemical methods used to identify lactobacilli. In addition, we evaluated the importance of nutritional characteristics in these results. We have also shown a method associating the requirements for amino acids and bases with certain fermentable characteristics of carbohydrates would allow a satisfactory identification of strains of the genus Lactobacilli.

\subsection{Enumeration of FMAT (ISO standard 4833) and coliforms (ISO 4832; February, 2006).}

We observe a presence of FMAT, CT and CF in most vegetables with percentages deferred from one vegetable to another. On the other hand, a total absence of the three for potatoes and carrots (Table 4).

Regarding the fruits, FMAT, CT, CF are present in all the fruits studied with the exception of the pastic, one also notices a total absence of CT and CF in the banana (Table 5).

Table 3: Biochemical characters

\begin{tabular}{|c|c|c|c|c|c|c|c|c|c|c|c|c|c|c|c|c|c|c|c|c|c|c|}
\hline Strains & Oxidase & catalase & ONPG & ADH & LDC & ODC & CIT & H2S & UREA & ADD & IND & VP & GEL & GLUE & MAN & INO & SOR & RHA & BAG & EMAIL & AMY & ARA \\
\hline E.Coli & - & + & + & - & + & + & - & - & - & - & + & - & - & + & + & - & + & + & - & + & - & + \\
\hline Salmonella & - & + & - & & + & & + & + & - & - & - & - & & + & & & & & & & & \\
\hline Shegilla & - & - & - & - & - & - & - & - & - & - & - & - & - & - & + & - & - & - & - & - & & + \\
\hline Clostridium & - & - & + & & + & + & + & + & - & & - & - & + & + & + & - & - & - & + & - & & - \\
\hline S.aureus & - & - & + & - & & & & & - & & & - & & + & - & & - & & & - & & - \\
\hline Proteus & + & & - & - & - & + & $\mathrm{v}$ & + & + & + & - & - & $\mathrm{v}$ & + & - & - & - & - & $\mathrm{v}$ & - & - & - \\
\hline Pseudomonas & + & + & - & + & - & - & + & - & - & - & - & - & + & - & & & & & & & & \\
\hline
\end{tabular}

Key: (+): Presence (-): Absence

*Corresponding author: rahma.erahioui@uit.ac.ma 
Table 4: FMAT, CT and CF for vegetables in $\log 10$ $\mathrm{CFU} / \mathrm{ml}$

\begin{tabular}{|l|l|l|l|}
\hline Samples & $\begin{array}{l}\text { FMAT } \\
\text { Log 10 } \\
\text { UfC / ml) }\end{array}$ & $\begin{array}{l}\text { CT (Log } \\
10 \text { UfC / } \\
\mathrm{ml})\end{array}$ & $\begin{array}{l}\text { CF (Log 10 UfC } \\
\text { ml) }\end{array}$ \\
\hline Potato & - & - & - \\
\hline Tomato & 3.24 & 2,3 & 1.4 \\
\hline Onion & 2.25 & 1.92 & 1.13 \\
\hline Carrot & - & - & - \\
\hline Eggplant & 6.42 & - & - \\
\hline Courgette & 6.43 & 5.95 & 5.62 \\
\hline Pepper & 6.87 & 5.5 & - \\
\hline Cucumber & 6.41 & 6.46 & 6.38 \\
\hline Turnip & 8.46 & 8,22 & 8.03 \\
\hline Pumpkin & 8,41 & 8.2 & 7.65 \\
\hline
\end{tabular}

FMAT: total aerobic mesophilic flora CT: total coliforms

Table 5: FMAT, CT and CF for fruits in Log $10 \mathrm{CFU} / \mathrm{ml}$

\begin{tabular}{|c|c|c|c|}
\hline Samples & $\begin{array}{l}\text { FMAT (Log } \\
\mathbf{1 0} \text { UfC / } \\
\text { ml) }\end{array}$ & $\begin{array}{l}\text { CT (Log 10 } \\
\text { UfC / ml) }\end{array}$ & $\begin{array}{l}\text { CF (Log } \\
\mathbf{1 0} \text { UfC / } \\
\text { ml) }\end{array}$ \\
\hline Banana & 8,38 & - & - \\
\hline Orange & 8.42 & 8,42 & 8.05 \\
\hline Strawberry & 8.16 & 7.72 & 7.53 \\
\hline Apple & 7.99 & 7.68 & 7.55 \\
\hline Melon & 7.97 & 7.89 & 7.72 \\
\hline Plastic & - & - & - \\
\hline Apricot & 6,08 & 6 & 5.84 \\
\hline Beet & 5.16 & 4.71 & 4.52 \\
\hline Lemon & 4.77 & 5.2 & 4.52 \\
\hline Pepper & 4.92 & 4.6 & 4.52 \\
\hline
\end{tabular}

FMAT: Total aerobic mesophilic flora

CT: Total coliforms

CF: Fecal coliforms

\subsection{Determination of the bacterial load of vegetables and fruits}

Fresh fruits and vegetables can be carriers of pathogenic microorganisms which come from organic fertilizers, contaminated irrigation water and this also depends from region to another [22]. So it is necessary to assess the risk and determine which criteria will be applied.

The bacterial loads (Escherichia. Coli, Streptococci, Staphylococcus aureus, Pseudomonas) are very high at the level of certain vegetables and fruits, while onion, potato, tomato, lemon and orange show a total absence of these bacteria. Moreover, all these products studied have a bacterial load that does not exceed $10 \log 10 \mathrm{CFU}$ $/ \mathrm{ml}$ and a total absence of Salmonella spp and Shegilla for all the foods studied (Table 6 and 7).

In this context, a study of lemon "published in the Journal of Environmental Health" was made by researchers from New York University, the results of their work indicate a wide variety of microorganisms even if it is considered to be an antibacterial [23].

According to a study of the Microbiological Assessment and the Origins of Contamination of 4th Range Products Sold in Abidjan Markets, Cote D'ivoire analysis of the survey sheets shows that vegetables and fruits constituting the raw materials of 4th range products manufactured are not subject to control and no health certificate is admitted to traders. In some cases, fruits and vegetables that are injured, overripe, sore or attacked by microorganisms are used. In general, the material comes from the fruit port and is composed of nonconforming products [24]. 
Table 6: The bacterial load of different strains in vegetables

\begin{tabular}{|c|c|c|c|c|c|c|}
\hline Samples & $\begin{array}{l}\text { E.coli (Log } 10 \text { UfC } \\
/ \mathrm{ml})\end{array}$ & $\begin{array}{l}\text { Strep (Log } 10 \\
\text { UfC / ml) }\end{array}$ & \begin{tabular}{|l} 
Staph (Log 10 \\
UfC / ml)
\end{tabular} & $\begin{array}{l}\text { nickname (Log } \\
10 \mathrm{UfC} / \mathrm{ml} \text { ) }\end{array}$ & $\begin{array}{l}\text { salmonella (Log } \\
10 \mathrm{UfC} / \mathrm{ml})\end{array}$ & $\begin{array}{l}\text { Shegilla } \\
\text { (Log } 10 \text { UfC / } \\
\text { ml) }\end{array}$ \\
\hline Potato & - & - & - & - & - & - \\
\hline Tomato & - & - & - & - & - & - \\
\hline Onion & - & - & - & - & - & - \\
\hline Carrot & 5.79 & - & - & - & - & - \\
\hline Eggplant & & 6.37 & 6.34 & - & - & - \\
\hline Courgette & - & - & 5.52 & - & - & - \\
\hline Pepper & - & 6.38 & - & - & - & - \\
\hline Cucumber & - & - & 5,83 & - & - & - \\
\hline Turnip & 8.37 & - & 8.19 & 8.4 & - & - \\
\hline Pumpkin & 8.18 & 8 & 8.15 & 7.92 & - & - \\
\hline
\end{tabular}

FMAT: total aerobic mesophilic flora CT: total coliforms $\quad$ CF: fecal coliforms

Table 7: The bacterial load of different strains in fruits

\begin{tabular}{|c|c|c|c|c|c|c|}
\hline Samples & $\begin{array}{l}\text { E.coli (Log } 10 \text { UfC / } \\
\text { ml) }\end{array}$ & $\begin{array}{l}/ \text { strep (Log } 10 \text { UfC } \\
/ \mathrm{ml})\end{array}$ & $\begin{array}{l}\text { Staph } \\
\text { (Log } \\
10 \text { UfC / ml) }\end{array}$ & $\begin{array}{l}\text { nickname (Log } \\
10 \text { UfC / ml) }\end{array}$ & $\begin{array}{l}\text { Salmonella (Log } \\
10 \mathrm{UfC} / \mathrm{ml})\end{array}$ & \begin{tabular}{|l} 
Shegilla \\
(Log10 UfC / \\
ml)
\end{tabular} \\
\hline Banana & - & - & 7.73 & - & - & - \\
\hline Orange & - & - & - & - & - & - \\
\hline Strawberry & 8.09 & - & 8.05 & 8.24 & - & - \\
\hline Apple & 7.73 & - & - & - & - & - \\
\hline Melon & 7.63 & - & - & - & - & - \\
\hline Plastic & 8.42 & 7.53 & 7.86 & - & - & - \\
\hline Apricot & - & - & 7.03 & - & - & - \\
\hline Beet & 5.63 & - & 5.55 & - & - & - \\
\hline Lemon & - & - & - & - & - & - \\
\hline Pepper & 4.62 & - & 4.68 & - & - & - \\
\hline
\end{tabular}

soil, dust, water and various harvesting methods or post-

The 20 samples of vegetables and fruits analyzed, 15 showed a bacterial load. These high levels of microbial contamination and the presence of pathogenic bacteria reflect the poor hygienic quality of vegetables and fruits marketed which could be due to the poor production and transport conditions of these foods on the production and distribution circuits.

The results of the microbiological analyzes indicate that $75 \%$ of the samples analyzed are unfit for consumption.

This testifies to unhygienic and incorrect handling of vegetables and fruits. Great vigilance is required for the consumer vis-à-vis salads, especially when it is consumed raw. Vegetables and fruits are generally exposed to microbial contamination through contact with harvest treatments. Therefore, they harbor different types of pathogenic microorganisms for humans and for the plant itself [25].

Study says that the cause of contamination may be through irrigation water, transport and individual management by retailers may be the cause 16 . Potential sources of these pathogens are soil, faeces (animal and humans), water (irrigation, cleaning), animals (including insects and birds) [26].

In fruit and vegetable markets, staff should first be sensitized to hygiene and the problem of food poisoning. The prevalence of the most important bacterial load in vegetables, is that of pumpkin and turnip with four strains (E. coli, staphylococcus pseudomonas and

*Corresponding author: rahma.erahioui@uit.ac.ma 
streptococci) and three strains (E. coli, staphylococcus and pseudomonas) respectively ((figure 1).

Regarding fruit prevalence of bacterial loads, we find the strawberry by three strains such as E. coli, staphylococcus and pseudomonas (figure 2).

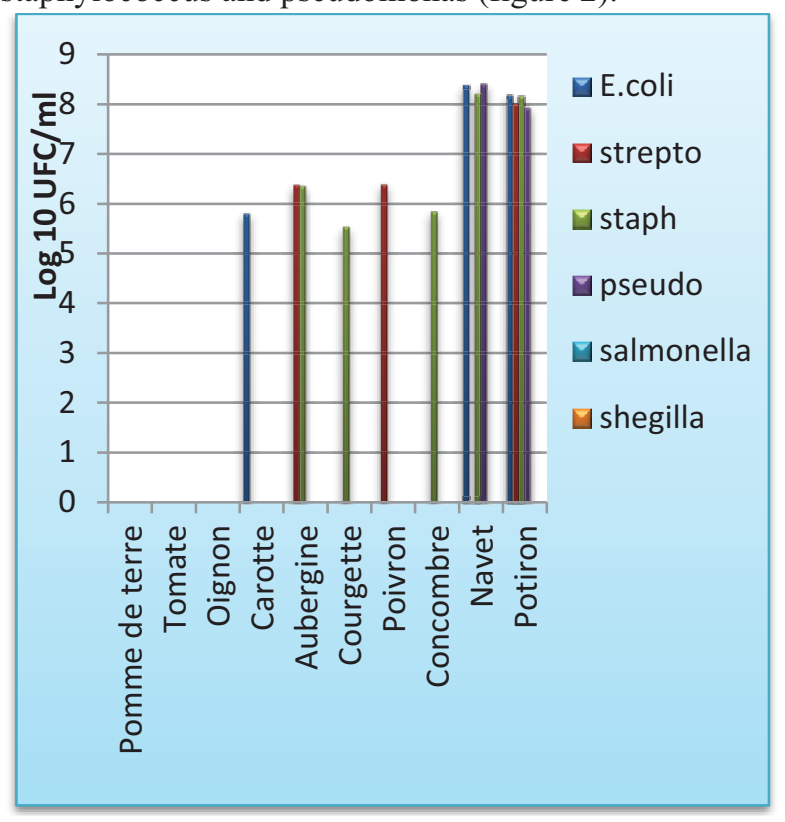

Fig 1: Prevalence of strains in vegetable deferens

The prevalence of the most important bacterial load in vegetables, is that of pumpkin and turnip with four strains (E. coli, staphylococcus pseudomonas and streptococcus) and three strains (E. coli, staphylococcus and pseudomonas) respectively ((figure 1).

Regarding fruit prevalence of bacterial loads, we find the strawberry by three strains such as E. coli, staphylococcus and pseudomonas (figure 2).

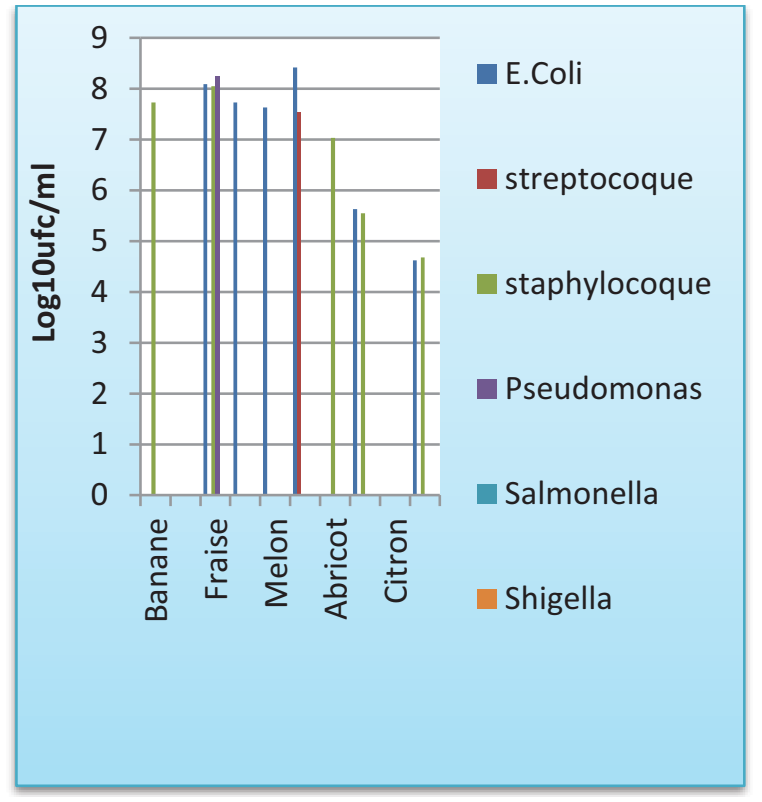

Fig 2: Prevalence of strains in vas deferens

*Corresponding author: rahma.erahioui@uit.ac.ma

\section{Conclusion}

The microbiological analysis of vegetables and fruits ready for public consumption shows contamination by various germs (Clostridium, Staphylococcus aureus, E. coli), which poses a risk for the consumer. This contamination problem can be caused by various factors such as environmental problems (pollution of water resources) and the use of animal fertilizers for treatments. Therefore, it is necessary to define good hygiene practices for the purchase of fruits and vegetables.

To avoid poisoning by fruits and vegetables, wash your hands before and after handling a raw food afterwards, it is essential to adopt certain practices, in particular the passage of raw fruits and vegetables under lukewarm water before to eat or cook them, it is also advisable to wash what has touched the raw food to avoid crosscontamination from hands, countertops, kitchen utensils or the refrigerator to other food.

\section{References}

1. MJ .Amiot-Carlin, F. Caillavet, M. Causse, P. Combris, J. Dallonge ville, M. Padilla, C. Renard, LG Soler (editors),. Fruits and vegetables in the diet. Stakes and determinants of consumption. Collective scientific expertise, summary of the report, INRA (France), 80 p (2007).

2. Louise Atchibri Anin et al, Microbiological Evaluation And Origins Of Contamination Of 4th Range Products Sold In Abidjan Markets, Cote D'ivoire Article in European Scientific Journal (December 2016).

3. D. DESBORDES, Microbiological quality of fruits and vegetables: flora, deterioration, health risks, prevention, Under the direction of Marie Jeanne Blachier Teacher Researcher at ISARA 31 place Belle cour 69002 LYON (February 2003).

4. Belomaria.M., Ahami.AOT, Aboussaleh. Y., Elbouhali.B., Cherrah.Y., Soulaymani.A., .Environmental origin of collective food poisoning in Morocco: Case of the Gharb Chrarda Bni Hssen region, Antropo, 14, 83-88. www.didac.ehu.es/antropo (2007).

5. MENG et al, Introduction. Microbiological food safety, Microbes and Infection, vol. 4, n ${ }^{\circ} 4$, pp. 395-397 (2002).

6. Ministry of Agriculture and Food. Bacterial food poisoning, 2011.

7. Boukarou. L and Boulhares.Z, Investigation of a food poisoning infection in the wilaya of bouira, (July 2, 2018). 
8. COLLECTIVE RESTORATION AND (GEMRCN), GUIDE FOR THE PUBLIC PURCHASE OF FRESH FRUITS, VEGETABLES AND POTATOES; This guide, validated on April 27, 2012 by the Scientific Council of the Economic Observatory of Public Purchasing (OEAP), relating to fruits, vegetables and apples. earth in the fresh state. replaces the GEMRCN guide $n{ }^{\circ}$ F9-02 of January 28, (2003).

9. Dr NASSRI .I, Food hygiene and health risk, March (2014).

10. ISO 6887-4: 2017 Microbiology of the food chain, Preparation of samples, initial suspension and decimal dilutions for microbiological examination, Part 4: Specific rules for the preparation of various products.

11. R.Nouria Benamara and al,. Identification and characterization of Bacillus cereus spores isolated from processed cheese produced in Algeria (2016/2017).

12. ISO 4833 .,Horizontal method for the enumeration of microorganisms V08-011: 1-9(2003).

13. French Association for Standardization, NF V 08051-December 1992, Method for research and enumeration of total aerobic mesophilic flora Paris: AFNOR, (December 1992).

14. ISO 4832: 2006. Food microbiology Horizontal method for the enumeration of coliforms Colony count method (2006).

15. ISO 16649-2. Microbiology of food 'Horizontal method for the enumeration of beta-glucuronidase positive Escherichia coli' Part 2: Colony count technique at 44 degrees $\mathrm{C}$ using 5-bromo-4-chloro3-indolyl beta-D-glucuronate (2001).

16. NM ISO 6888-1., Food microbiology horizontal method for the enumeration of coagulass positive staphylococci (Staphylococcus aureus and other species) - Part 1: Techniques using Baird-Parker agar medium; Rev, IC08.0.150, 21( 2008).

17. ANONYMOUS, 2005NF EN ISO 7937 AFNOR, PARIS (2005).

18. ISO 6579: 2002. Microbial Microbiology of food and animal feeding stuffs Horizontal method for the detection of Salmonella spp. This standard has been replaced byISO 6579-1 (2017).

19. SEYDI.M,SYLLAK.S.B,MUSABYEMYEMARYA .Level of bacterial contamination of the legs of frozen chickens imported into Senegal. Review. [RASPA, 2 (3-4): 24 1-244 ( 2 004).

20. M.EL BOUAMRI, MOLECULAR EPIDEMIO STUDY OF ENTEROBACTERIA PRODUCING ENLARGED SPECTRUM $\beta$-LACTAMASES AT MARRAKECH CHU. July 12, (2017).

21. K. Side larbi, M.Stambouli-MASCARA-DES University in microbiology, Internship report in a medical sector (2007).

\footnotetext{
"Corresponding author: rahma.erahioui@uit.ac.ma
}

22. Maude Michaud Dumont, microbiologist, Ph. D., MAPAQ Research and writing 2019 edition, GUIDELINES AND STANDARDS FOR THE INTERPRETATION OF ANALYTICAL RESULTS IN FOOD MICROBIOLOGY,(2019).

23. P. tierno, professor of microbiology and pathology at the Langone medical center at New York University,journals of Environmental Health, (2014).

24. Louise Atchibri Anin, EVALUATION Microbiological And Origins Of Contamination Of 4th Range Products Sold On The Markets Of Abidjan, Cote D'ivoire Laboratory Of Nutrition And Food Safety (LANUSA) doi: 10.19044 / esj.v12n36p273.(2016).

25. Lopez Camelo, A. F. Manual for the preparation and sale of fruits and vegetables. From field to market. FAO Agricultural Services Bulletin (FAO) (2007).

26. Ofor.MO, Okorie.VC, Ibeawuchi.II, Ihejirika.GO, Obilo. OP \& Dialoke. SA ,.Microbial contaminants in fresh tomato wash water and food safety considerations in South-Eastern Nigeria. Life Sci. J, 1, 80-82 (2009). 